\title{
Impact of HPV Status and AurkA Phe31lle Polymorphism on The Response to Cetuximab Treatment of Head and Neck Squamous Cell Carcinoma (HNSCC) Patients
}

Julia Muth ( $\nabla$ julia.muth@tum.de )

Klinikum rechts der Isar der Technischen Universitat Munchen Klinik und Poliklinik fur Hals- Nasen- und Ohrenheilkunde https://orcid.org/0000-0003-0141-040X

\section{Andreas Roth}

Klinikum rechts der Isar der Technischen Universitat Munchen Klinik und Poliklinik fur Hals- Nasen- und Ohrenheilkunde

\section{Michael Siegl}

Klinikum rechts der Isar der Technischen Universitat Munchen Klinik und Poliklinik fur Hals- Nasen- und Ohrenheilkunde

\section{Guido Piontek}

Klinikum der Universität München Institut für Pathologie

\section{Rudolf Reiter}

Universitätsklinikum Ulm Klinik für Hals-Nasen-Ohrenheilkunde

\section{Markus Wirth}

Klinikum rechts der Isar der Technischen Universitat Munchen Klinik und Poliklinik fur Hals- Nasen- und Ohrenheilkunde

\section{Gero Brockhoff}

Universitätsklinikum Regensburg Klinik für Frauenheilkunde und Geburtshilfe

\section{Wilko Weichert}

Klinikum rechts der Isar der Technischen Universität München Institut für Pathologie

\section{Anja Pickhard}

Klinikum rechts der Isar der Technischen Universitat Munchen Klinik und Poliklinik fur Hals- Nasen- und Ohrenheilkunde

\section{Research}

Keywords: Aurora kinase A, Aurora Kinases, Papillomaviridae, Cetuximab, Squamous Cell Carcinoma of Head and Neck, Head and Neck Neoplasms, Molecular Targeted Therapy 
DOl: https://doi.org/10.21203/rs.3.rs-104557/v1

License: (c) (1) This work is licensed under a Creative Commons Attribution 4.0 International License. Read Full License 


\section{Abstract}

Background: Since 2004, the use of the monoclonal antibody cetuximab has been preferred over platinum-based therapy for patients with advanced Head and neck squamous cell carcinoma (HNSCC). However, the response rate to the treatment is only around $20 \%$. Currently, no biomarkers have been identified to differentiate potential responders from non-responders to cetuximab therapy.

Methods: We evaluated the predictive and prognostic properties of AurkA polymorphism and HPV infection in HNSCC patients treated with cetuximab. Clinical data of 434 patients was collected and tissue was analyzed for AurkA polymorphism using PCR. Immunohistochemistry was used to stain for various markers and their expression levels were scored. Cell culture experiments were performed to complement clinical findings.

Results: We demonstrated in vivo as well as in vitro that both AurkA polymorphism and HPV status have predictive and prognostic value.

Conclusions: AurkA polymorphism and HPV status could be beneficial for response prediction and therapy optimization for HNSCC patients.

\section{Background}

Head and neck squamous cell carcinoma (HNSCC) is the sixth most common malignant tumor worldwide, the seventh most common cause of all tumor-related deaths, and the most common head and neck cancer (90\%) [1-3]. There are approximately 630,000 new cases of HNSCC worldwide every year, of which approximately 350,000 are lethal [4].

The molecular drivers of head and neck cancer have not yet been fully elucidated. However, there are several known risk factors for HNSCC. In addition to alcohol and tobacco abuse, exposure to viral oncogenes is also a risk factor for head and neck cancer [5]. Moreover, human papillomavirus (HPV) has strong oncogenic potential and can contribute to tumorigenesis via its oncoproteins E6 and E7 [6]. Although HPV has long been recognized as a risk factor in many tumor entities, association with HNSCC was only demonstrated a few years ago [7]. HPV-positive HNSCC has the highest prevalence in the oropharynx at $35.6 \%$ [8-11]. High-risk HPV-16 is present in $90 \%$ of HPV-associated HNSCC [12]; in these cases, wild type p53 is mostly present but its function is diminished by the activity of the viral oncogene E6 [13].

Another clinically relevant biomolecular marker with oncogenic potential is the Epidermal Growth Factor Receptor (EGFR). This receptor tyrosine kinase is over-expressed in approximately $90 \%$ of HNSCC cases [14-16], and abnormal activity is caused by gene amplification in $10-17 \%$ of HNSCC cases [17-20]. However, EGFR expression is not found homogenously in different anatomical localizations of head and neck, but its expression is significantly higher in carcinomas of the oral cavity and the oropharynx than in laryngeal carcinomas [14]. 
Cetuximab is a chimeric (65\% human and $35 \%$ mouse) monoclonal IgG1 antibody directed against the extracellular binding domain of the EGFR [21]. The antibody competes with the receptor for ligand binding and upon binding causes receptor internalization and degradation [22, 23].

Aurora kinases (Aurks) were described in 1995 by David Glover et al. [24, 25]. Aurks are cell cycle regulating serine-threonine kinases. In humans, the Aurk family comprises three members: Aurora kinase $A, B$, and $C$ [26]. Aurora kinases A and B play pivotal roles in the regulation of cell division, especially during entry into mitosis by the formation of a functional microtubule spindle apparatus and in the completion of cytokinesis [27]. Overexpression of Aurora kinase A exists in tissues with a high mitotic index, e.g., in the thymus or embryo, as well as in many tumor types, including carcinomas of the colon, breast, stomach, ovary, non-small cell lung carcinoma, and in squamous cell carcinoma of the head and neck [28-30, 27, 31-33]. Overexpression in tumor tissues is usually caused by AurkA gene amplification [34]. Recently, the amplification of chromosome $20 q$ has been observed in a wide variety of tumor types as an important mechanism of enhanced AurkA gene dosage [35, 36]. Overall, an increased number of AurkA genes seem to be clinically associated with more aggressive cancer, independent of the molecular mechanism that causes an enhanced gene dose [37, 33].

An AurkA genetic polymorphism has been described, in which the amino acid phenylalanine (Phe) at position 31 is replaced by isoleucine (Ile) as a result of different coding regions [38]. In the case of esophageal carcinoma, the Phe31lle polymorphism has been classified as a risk factor for both tumor occurrence and progression [31]. Since 2004, the therapeutic application of the monoclonal antibody cetuximab has been preferred over platinum-based chemotherapy for the treatment of patients with advanced HNSCC. We have previously shown that in vitro, the response rate to cetuximab treatment was higher in patients with the homozygous polymorphism [39].

\section{Methods}

\section{Aim, design and setting of the study}

Response to cetuximab therapy in patients with HNSCC is only around $20 \%$, and currently, neither prognostic nor predictive biomarkers have been identified to stratify patients with respect to potential response vs. non-response to cetuximab.

The aim of the present study was to investigate the HPV status, and in particular the Aurora kinase A polymorphism, in terms of their predictive and prognostic value in patients with HNSCC treated with cetuximab therapy.

Clinical data from patients with HNSCC was retrospectively analyzed. In vitro experiments were performed to complement clinical data collected.

\section{Clinical data and experimental procedures}




\section{Patient population}

FFPE tissues from 434 patients with squamous cell carcinoma of the oral cavity, oropharynx, hypopharynx, and larynx were used. Both tumor tissue and corresponding normal tissue from the same patient were examined. The included patients were treated at the ENT hospital, Klinikum rechts der Isar, Technical University Munich, at the ENT department of the University of Regensburg and the ENT department of the University of Heidelberg. The patients received either surgery, primary chemoradiotherapy (combined with cetuximab in many cases), or palliative chemo- or immunotherapy. The inclusion criterion was admittance to one of the three hospitals from 1988 to 2015. Histological and clinical data were collected from medical records, and information from the Munich Cancer Registry was used for the collection of survival data. Patient characteristics are enumerated in Table 1. All tumors were reclassified according to the International Union Against Cancer (UICC) TNM Classification System of 2002. The study was approved by the Ethics Committee of the Klinikum rechts der Isar, Technical University Munich (project number 1420/05). 
Table 1

Patient characteristics.

\begin{tabular}{|c|c|c|}
\hline Patient characteristics & \multicolumn{2}{|c|}{$\operatorname{HNSCC}(n=434)$} \\
\hline \multicolumn{3}{|l|}{ Age - years } \\
\hline Median & \multicolumn{2}{|l|}{73} \\
\hline Range & \multicolumn{2}{|c|}{$56-90$} \\
\hline \multicolumn{3}{|l|}{ Sex } \\
\hline Male & 362 & $83.4 \%$ \\
\hline Female & 72 & $16.6 \%$ \\
\hline \multicolumn{3}{|l|}{ T-Stage } \\
\hline T1 & 42 & $9.7 \%$ \\
\hline $\mathrm{T} 2$ & 114 & $26.3 \%$ \\
\hline T3 & 100 & $23.0 \%$ \\
\hline $\mathrm{T} 4 \mathrm{a}$ & 124 & $28.6 \%$ \\
\hline $\mathrm{T} 4 \mathrm{~b}$ & 1 & $0.2 \%$ \\
\hline Tx & 1 & $0.2 \%$ \\
\hline Unknown & 52 & $12.0 \%$ \\
\hline \multicolumn{3}{|l|}{ N-Stage } \\
\hline No & 132 & $30.4 \%$ \\
\hline N1 & 41 & $9.4 \%$ \\
\hline N2a & 9 & $2.1 \%$ \\
\hline N2b & 93 & $21.4 \%$ \\
\hline N2c & 92 & $21.2 \%$ \\
\hline N3 & 10 & $2.3 \%$ \\
\hline Nx & 3 & $0.7 \%$ \\
\hline Unknown & 54 & $12.4 \%$ \\
\hline \multicolumn{3}{|l|}{ M-Stage } \\
\hline MO & 348 & $80.2 \%$ \\
\hline M1 & 13 & $3.0 \%$ \\
\hline$M x$ & 20 & $4.6 \%$ \\
\hline
\end{tabular}




\begin{tabular}{|c|c|c|}
\hline \multirow{2}{*}{$\begin{array}{l}\text { Patient characteristics } \\
\text { Unknown }\end{array}$} & \multicolumn{2}{|c|}{$\operatorname{HNSCC}(n=434)$} \\
\hline & 53 & $12.2 \%$ \\
\hline \multicolumn{3}{|l|}{ Grading } \\
\hline G1 & 21 & $4.8 \%$ \\
\hline $\mathrm{G} 2$ & 185 & $42.6 \%$ \\
\hline G3 & 130 & $30.0 \%$ \\
\hline $\mathrm{Gx}$ & 7 & $1.6 \%$ \\
\hline Unknown & 91 & $21.0 \%$ \\
\hline \multicolumn{3}{|l|}{ Stage } \\
\hline Stage I & 29 & $6.7 \%$ \\
\hline Stage II & 55 & $12.7 \%$ \\
\hline Stage III & 58 & $13.4 \%$ \\
\hline Stage IVA & 213 & $49.1 \%$ \\
\hline Stage IVB & 17 & $3.9 \%$ \\
\hline Stage IVC & 6 & $1.4 \%$ \\
\hline Unknown & 51 & $11.8 \%$ \\
\hline \multicolumn{3}{|l|}{ Localisation } \\
\hline Oral cavity & 85 & $19.6 \%$ \\
\hline Oropharynx & 151 & $34.8 \%$ \\
\hline Hypopharynx & 94 & $21.7 \%$ \\
\hline Larynx & 99 & $22.8 \%$ \\
\hline Other & 4 & $0.9 \%$ \\
\hline \multicolumn{3}{|l|}{ Alcohol consumption } \\
\hline Regularly & 183 & $42.2 \%$ \\
\hline Irregular & 80 & $18.4 \%$ \\
\hline Unknown & 171 & $39.4 \%$ \\
\hline \multicolumn{3}{|l|}{ Tobacco use } \\
\hline Smoker & 208 & $47.9 \%$ \\
\hline Non-/ Ex-smoker & 80 & $18.4 \%$ \\
\hline
\end{tabular}




\section{Patient characteristics $\operatorname{HNSCC}(n=434)$

Unknown $\quad 146 \quad 33.6 \%$ \\ PCR-restriction fragment length polymorphism (RFLP)}

DNA was isolated from cell lines and FFPE tumor samples using the DNeasy Kit (Qiagen, Hilden, Germany) according to the manufacturer's instructions.

Specific PCR for AurkA genotypes at the Phe31lle site was performed using the Taq-DNA Polymerase Allinclusive Kit (PeqLab, Erlangen, Germany) according the manufacturer's guidelines. We applied the following PCR program: $95^{\circ} \mathrm{C}$ for $5 \mathrm{~min}, 30$ cycles of $95^{\circ} \mathrm{C}$ for $30 \mathrm{~s}, 60^{\circ} \mathrm{C}$ annealing for $30 \mathrm{~s}, 72{ }^{\circ} \mathrm{C}$ for $30 \mathrm{~s}$, and $72{ }^{\circ} \mathrm{C}$ for $7 \mathrm{~min}$ on a thermocycler (BioRad, Munich, Germany). The following primers were used: AurkA forward: CTTTCATGAATGCCAGAAAGTT; AurkA reverse: CTGGGAAGAATTTGAAGGACA. The 165bp PCR products were digested with Apol (New England BioLabs, Inc., Beverly, USA) and separated on a $2.5 \%$ agarose gel. Digestion of the AurkA 31Phe allele results in two fragments (153 bp and $12 \mathrm{bp}$ ); since the AurkA 31lle allele contains an additional third Apol restriction site, three fragments (89 bp, 64 bp, and $12 \mathrm{bp}$ ) are generated after digestion. The results were further confirmed by DNA sequencing using an $A B I$ 3100 DNA sequencer (Life Technologies, Darmstadt, Germany).

\section{Immunohistochemical study}

Fresh $1.5 \mu \mathrm{m}$ sections were transferred to glass slides, deparaffined, and rehydrated. An antigen retrieval method (microwave activation in citrate buffered saline) was applied following the instructions provided by the manufacturer. After cooling, the slides were incubated with the following antibodies: Aurora-Kinase A (rabbit, clone 1F8) 1:200 (Cell Signaling Technology, Frankfurt, Germany), Aurora-Kinase B (rabbit) 1:200 (Cell Signaling Technology), Survivin (rabbit, clone 12C4) 1:100 (Dako Agilent Technologies, Hamburg, Germany), p-Akt Ser473 (rabbit, clone 736E11) 1:20 (Cell Signaling Technology). The reaction was developed with the labeled streptavidin-biotin-peroxidase system. The expression of p16 ${ }^{\text {INK4a }}$ was assessed using an auto staining system (Leica Bond-Max), the BOND Polymer Refine Detection Kit (both from Leica Microsystems $\mathrm{GmbH}$ ), and a monoclonal mouse antibody (Roche Diagnostics $\mathrm{GmbH}$, Mannheim, Germany). 3,3'-Diaminobenzidin (DAB) was used as the reaction indicator. After counterstaining with hematoxylin, slides were dehydrated in ascending concentrations with ethanol and mounted. Tissues with known expression of the respective antigen were used as positive controls, and for negative controls, irrelevant antibodies with the correct immunoglobulin isotypes were used (Fig. 5).

\section{Scoring system for protein expression in immunohistochemical staining}

A scoring system was applied to describe the expression levels of the proteins AurkA, AurkB, Survivin, and p-Akt Ser473. The stained tumor areas were dichotomized as follows: Adopted from Schauer et al., we used an immunostaining score comprised of intensity and a stained tumor area that had values between 
0 and 7 [40]. To perform the statistical analysis, we set a cut-off at 2 and divided the samples into positive and negative. p16 ${ }^{\text {INK } 4 \mathrm{a}}$ was considered to be positive when it was defined as strong and diffuse nuclear and cytoplasmic staining in $\geq 70 \%$ of the tumor cells, which is the same scoring criteria used in the study by Ang et al. [41].

\section{Cell culture}

For the investigation of the influence of the Aurora kinase A polymorphism and the HPV status in vitro, four suitable cell lines were used for the proliferation analyzes: UD-SCC-2 (AurkA Phe/Phe, HPV positive), UD-SCC-5 (AurkA Phe/Phe, HPV negative), UP-SCC-154 (AurkA Phe/lle, HPV positive), SAS (AurkA Phe/lle, HPV negative).

The cell lines UP-SCC-154 and SAS were obtained from DSMZ (Braunschweig, Germany), and the cell lines UD-SCC-2 and UD-SCC-5 were provided by the University of Düsseldorf (Clinic for Otolaryngology, Düsseldorf, Germany).

Cells were cultured in Dulbecco's modified Eagle medium (DMEM) or RPMI 1640 medium (Invitrogen, Darmstadt, Germany) containing 10\% fetal calf serum (FCS) (Biochrom, Berlin, Germany), 2 mM glutamine, $100 \mu \mathrm{g} / \mathrm{ml}$ streptomycin, and $100 \mathrm{U} / \mathrm{ml}$ penicillin (Biochrom) and maintained at $37^{\circ} \mathrm{C}$ in an atmosphere of $5 \% \mathrm{CO}_{2}$ grown to a $70-90 \%$ confluence. Cells were treated with docetaxel $(0.25 \mathrm{nM})$ (Selleckchem, Houston, TX, USA) and cetuximab (Erbitux ${ }^{\circledR}$ ) (50 nM) (Merck KGaA, Darmstadt, Germany).

\section{Analysis of cell proliferation}

The binding of crystal violet to cellular DNA was used to assess cell proliferation via photometry. Cells were seeded at a density of $5 \times 10^{3}$ cells per well in six-well plates $24 \mathrm{~h}$ before treatment. Ten days after treatment with the inhibitors, the culture medium was aspirated and $500 \mu \mathrm{L}$ of $4 \%$ formaldehyde was added to each well for 15 minutes. After washing with $0.1 \%$ Triton- $\mathrm{X} 100 / 1 \times$ PBS and $\mathrm{H}_{2} \mathrm{O}$, crystal violet $(0.04 \%)$ was added to the fixed cells and incubated for 30 minutes. Finally, after removing excess crystal violet, SDS (1\%) was added, and the optical density was measured at $595 \mathrm{~nm}$ using a microplate photometer after $1 \mathrm{~h}$.

\section{Colony formation assay}

Cell survival after treatment with inhibitors was assessed using a colony formation assay (CFA). The cells were seeded in six-well plates $\left(5 \times 10^{2}\right.$ cells per well) and allowed to adhere overnight at $37^{\circ} \mathrm{C}$. The following day, the cells were treated and incubated at $37^{\circ} \mathrm{C}$ for 10 days. The cell colonies were then formalin fixed ( $4 \%$ formaldehyde) and visualized by crystal violet $(0.04 \%)$ staining (Sigma-Aldrich, Steinheim, Germany). The colonies were counted after rinsing off the dye. Colony numbers were depicted as the percentage of colonies from untreated cells.

\section{Western blot}


For protein expression analysis, cells were lysed in 1x lysis buffer (New England Biolabs, Frankfurt, Germany) supplemented with $1 \mathrm{mM}$ PMSF (Roth, Karlsruhe, Germany). Equal amounts of protein (15 $\mathrm{\mu g}$ ) were separated by SDS-PAGE and transferred to Immobilion membranes (Millipore, Schwalbach, Germany). Blocking of unspecific binding sites was performed using $5 \%(w / v)$ non-fat dry milk powder or $5 \%$ bovine serum albumin in $1 \times$ TBST. Membranes were incubated with primary antibodies diluted in $1 \mathrm{x}$ TBST for 14-16 hours at $4{ }^{\circ} \mathrm{C}$. HRP-conjugated immunoglobulins (diluted 1:5000 in 5\% non-fat dry milk/1x TBST) served as detection antibodies and were probed for $1 \mathrm{~h}$ at room temperature. Immunoreactivity was visualized using ChemiDocTM XRS + with ImageLab software 6.0 (BioRad, Munich, Germany). We used primary antibodies against p-Akt Ser473 (rabbit, clone D9E) 1:500 (Cell Signaling), Survivin (rabbit) 1:1000 (Cell Signaling), Aurora-Kinase A (rabbit) 1:500, Aurora-Kinase B (rabbit) 1:500, and Tubulin (rabbit) 1:5000.

\section{Aneuploidy analysis by flow cytometry}

After seeding in culture flasks $\left(75 \mathrm{~cm}^{2}, 5 \times 10^{5}\right.$ cells per flask) UD-SCC- 5 and SAS cells were fixed/permeabilized with $70 \%$ methanol overnight. Finally, cells were washed twice with $1 x$ PBS and resuspended in $1 \times$ PBS containing $1 \mu \mathrm{g} / \mathrm{ml}$ DAPI 15 min prior to analysis. $1 \times 10^{5}$ DAPI stained cells of every sample were analyzed using a BD FACSCanto-II ${ }^{\mathrm{TM}}$ flow cytometer (BD Biosciences, San Jose, USA). DNA histograms were plotted on a linear scale and cell cycle fractions, i.e., percentages of cells in G0/G1-, S-, and G2/M-phase, were quantified using ModFit LT 3.2 software (Verity Software House, Topsham, ME, USA) upon cell doublet, aggregate, and debris discrimination via pulse processing.

\section{Statistical analysis}

Statistical analysis was performed using GraphPad Prism software, version 7.0e. Assuming a symmetry correlation structure for all experiments, all hypotheses were tested with one-way ANOVA test, and the means of treated cells and untreated controls were compared by way of a t-test. The minimum level of statistical significance was set at $p<0.05$.

SPSS software version 23 was used to evaluate the clinical data. Using Kaplan-Meier analysis and the log rank test, the prognostic value of individual markers was evaluated. Correlation analysis for the clinical data (T-classification, lymph node metastasis, distant metastasis) was performed using a cross tabulation/fourfold table (chi-square test, Fisher's exact test).

\section{Results}

\section{PCR-restriction fragment length polymorphism (RFLP)}

The proportion of AurkA polymorphism was equivalent in tumor and normal tissue: We found a Phe/Phe, Phe/lle to lle/lle of $52.2 \%, 44.2-3.6 \%$ distribution and $58.5 \%, 41.5-0 \%$ in normal tissues. The data derived from polymorphism specific PCR and sequencing were equivalent.

\section{Proliferation assay}


Both HPV positive cell lines were very sensitive to the individual treatments. The strongest antiproliferative effect following treatment with cetuximab monotherapy, as well as the combination treatment, was observed in the HPV positive and AurkA heterozygous cell line UP-SCC-154. The combined application of cetuximab and docetaxel was even more efficient at inhibiting cell proliferation than the application of either substrate alone $(p=0.0017)$. The analysis of the Aurora kinase A heterozygous cell line SAS tended to show the same phenomenon.

Neither treatment with cetuximab alone nor the combination of cetuximab and docetaxel caused an efficient inhibition of the HPV negative AurkA homozygous cell line UD-SCC-5. Only cetuximab treatment resulted in a significant reduction in the survival of the SAS cell line.

Using advanced analysis we grouped and evaluated the results depending on the property. The results demonstrated that treatment with cetuximab caused a significantly more efficient response in HPV positive than in HPV negative cells (Fig. 1).

The antiproliferative effect was even more pronounced in AurkA heterozygotes compared to AurkA homozygous cell lines.

The most efficient inhibition of proliferation, by either single or combination treatments, was found in cells harboring both a heterozygous AurkA polymorphism and HPV infection. Combined treatment with cetuximab and docetaxel was even more efficient in HPV positive AurkA heterozygous cell lines than the application of cetuximab alone $(p=0.0017)$. This phenomenon appeared only as a trend in the AurkA heterozygous cell lines with HPV negative status $(p=0.0929)$. In contrast, in cells with homozygous AurkA polymorphism, regardless of the HPV status, no increased inhibition of proliferation by the additional use of docetaxel was observed.

\section{Colony formation assay}

In both HPV positive cell lines UD-SCC-2 and UP-SCC-154 the formation of proliferative colonies could be significantly reduced by the use of cetuximab alone or in combination with docetaxel, regardless of the Aurora kinase A polymorphism.

In HPV negative cell lines, the antiproliferative effect was significantly lower, while the UD-SCC-5 did not respond to the treatments at all.

In order to better evaluate the influence of the examined characteristics on the clonogenic survival of the cell lines, the results were regrouped and reevaluated depending on the property. The analysis revealed that the HPV positive cells were mostly sensitive to the treatments (Fig. 2).

In contrast, the application of cetuximab alone or in combination with docetaxel did not elicit any effect on the clonogenic survival of HPV negative cells.

Both cetuximab monotreatment and the combination treatment significantly reduced clonogenic formation of the AurkA homozygous and AurkA heterozygous cell lines, respectively (Fig. 2). However, 
there was no significant difference in terms of effect as a function of treatment in the group comparison.

In terms of the inhibition of clonogenic survival, overall, the most pronounced treatment efficiency with respect to the clonogenic survival was observed when cells with heterozygous Aurora kinase $A$ polymorphism were positive for HPV. In the heterozygous cell lines the combined use of cetuximab and docetaxel was more efficient compared to the application of cetuximab alone (AurkA heterozygous and HPV positive, $p=0.0852$; AurkA heterozygous and HPV negative, $p=0.0765$ ).

\section{Western blot analysis}

We evaluated Aurora kinase A and B, p-Akt Ser473, as well as Survivin expression on the protein level as a function of single (either cetuximab or docetaxel) and dual (combined cetuximab and docetaxel) treatment (Fig. 3)

The analysis revealed higher protein levels of Survivin, p-Akt Ser473, and Aurora kinase B in the heterozygous cell lines compared to the homozygous cell lines. Treatment of the cells, in particular with the combination of cetuximab and docetaxel, led to a reduction of AurkA protein expression in the HPV negative cell lines. The strongest effect was observed in the homozygous UD-SCC- 5 cell line.

\section{Ploidy analysis}

In order to show the relationship between the Aurora kinase A polymorphism and the potential genesis of polysomy/aneuploidy, the total cellular DNA content of the cells was determined by flow cytometry.

Figure 4 shows the relative DNA content by percentage chromosome distribution. While the two homozygous cell lines UD-SCC-2 and UD-SCC- 5 are mostly diploid, we also found tetraploid cells in the heterozygous cell lines UP-SCC-154 and SAS. This difference in the number of tetraploid cells between cell lines with different Aurora kinase A polymorphisms was significant $(p=0.019)$.

\section{Immunohistochemistry}

Comparison of the expression scores of the respective markers in the tumor or normal tissue by means of the Wilcoxon-Mann-Whitney test revealed a significantly higher expression of $p$-Akt Ser473 $(p=0.014)$, Survivin $(p=0.003)$, and Aurora kinase A $(p<0.001)$ in the tumor tissue compared to expression in nonmalignant tissues, while Aurora kinase $B$ expression was not significantly increased in tumor tissues $(p=$ 0.322).

Correlations between marker expression and clinical data were made by cross tabulation using the chisquare test, as well as Fisher's exact test for smaller numbers of cases. The clinical variables used were the T-stage, $\mathrm{N}$-stage, distant metastasis, as well as the stage of the tumor disease at the time of initial diagnosis.

A statistically significant correlation between marker expression and the clinical data was shown for the tumor size at first diagnosis and the expression of $\mathrm{p} 16^{\text {INK4a }}$. The expression of $\mathrm{p}$-Akt Ser473 and Aurora 
kinase A each correlated significantly with the grading of the tumor (Table 2).

Table 2

Correlation between marker expression and clinical data.

\begin{tabular}{|lllllll|}
\hline Marker & T-Stage & N-Stage & M-Stage & Grading & Stage \\
\hline & p-value & p-value & p-value & p-value & p-value \\
\hline p-Akt Ser473 & 0.830 & 0.817 & 0.715 & $\mathbf{0 . 0 0 3}$ & 0.493 \\
\hline Survivin & 0.290 & 0.619 & 0.294 & 0.272 & 0.773 \\
\hline AurkB & 0.263 & 0.643 & 0.327 & 0.207 & 0.179 \\
\hline AurkA & 0.641 & 0.609 & 0.575 & $\mathbf{0 . 0 4 6}$ & 0.770 \\
\hline p16 & $\mathbf{0 . 0 2 7}$ & 0.072 & 0.412 & 0.248 & 0.416 \\
\hline
\end{tabular}

Overall survival

By Kaplan-Maier analyses we verified prolonged overall survival for the entire collective, and especially for HPV positive patients under cetuximab therapy $(p=0.001)($ Fig. 6).

Furthermore, the clinical data revealed a significantly longer survival for patients with homozygous Aurora kinase A ( $p=0.048)$. The HPV status, as well as the Aurora kinase A polymorphisms, seem to play an important role in terms of therapeutic response to cetuximab treatment. The in vivo analysis revealed a positive trend for patients harboring a homozygous Phe/Phe Aurora kinase A.

\section{Discussion}

Due to the stable overexpression of EGFR in HNSCC, the introduction of anti-EGFR therapy with cetuximab in patients with HNSCC seemed very promising [42]. Yet, among other flaws, the response rate in patients only reaches around $20 \%$ [19]. Due to the complexity of the signaling pathways and the large number of proteins involved, the quest for predictive biomarkers for the response to cetuximab therapy remains inconclusive $[13,43]$.

Here we assessed the HPV infection status and the Aurora kinase A polymorphism as potential markers for cetuximab treatment efficacy.

The clinico-pathological characteristics of the HNSCC patient collective analyzed in this study were comparable to those reported elsewhere. Approximately $80 \%$ of all patients were male and the primary tumors were most often located in the oropharynx. Nicotine and alcohol abuse are known as the two most important risk factors for the development of HNSCC, which is also reflected by the demographic data of the study collective $[44,45]$.

Unlike in the US for instance, in Germany no standard therapy concept was carried out by default in the described collective over the observed time period. For each patient the treatment was rather adjusted 
individually, according to the stage of the disease, general condition, and patient's will. Hence, the treatment strategies to compare were heterogeneous and thus the number of cases in the individual groups were often very low.

\section{Comparison of the expression of Aurora kinases, p-Akt Ser473 and Survivin}

The first evidence that Aurora kinase A is overexpressed in solid tumors was reported in $1998[29,46]$. Accordingly, increased aurora kinase A protein levels could also be detected in the tumor tissue of HNSCC patients [27]. Here, we observed a significantly higher expression of Aurora kinase A in the tumor tissue compared to the corresponding normal tissue $(p<0.0001)$.

Consistent with the literature, a significantly elevated level of $p-A k t$ Ser473 $(p=0.014)$ and Survivin $(p=$ 0.003 ) in the tumor tissue was also recorded in the present patient collective [47-51]. It is well known that high levels of these proteins cause chromosomal instability and therefore contribute to carcinogenesis as an early hallmark [52-54].

Survivin not only plays a central role as an inhibitor of apoptosis but is also an integral part of the chromosomal passenger complex (CPC) [50]. Together with other proteins of the CPC, such as Aurora kinase B, Survivin is also involved in the regulation of cell division [55-57]. In turn, Aurora kinase Bdependent phosphorylation of histone $\mathrm{H} 3$ at Ser10 is required for the recruitment of this protein complex [58]. Thus, abnormal expression and activity of these molecules implies an unfavorable prognosis since they drive tumorigenesis and progression.

\section{Relationship between Aurora kinase A polymorphism and aneuploidy}

Both Aurora kinase A and Aurora kinase B play key roles in the regulation of cell division. While Aurora kinase $A$ is responsible for the correct separation of centrosomes during mitosis, Aurora kinase $B$ is an essential part of the chromosomal passenger complex (CPC). AurkB is therefore crucial for the correct chromosomal alignment in the equatorial plane as well as the attachment of the mitotic spindle to kinetochores [55].

Aurora kinase A is not only frequently overexpressed in tumor cells, but elevated levels of Aurora kinase A also cause chromosomal instability and thus errors in cytokinesis which ultimately lead to aneuploidy $[26,46,59]$. Although the molecular mechanisms differ, overexpression of Aurora kinase $B$ is also suspected to cause chromosomal instability $[60,61]$. Flow cytometric evaluation of the homozygous cell lines used in this study revealed predominantly diploid, and only rarely tetraploid, cells. In contrast, we observed an enormous increase in heterozygous cells in an aneuploid (i.e., tetraploid) state. This finding confirms previous work performed on SAS and UD-SCC- 5 cells treated with different inhibitors [62]. Most importantly, the formation of aneuploid cells occurred only in a heterozygous $\mathrm{HN}$ cell line (i.e., $\mathrm{HN}$ cells). 
In addition, the degree of aneuploidy could also be increased by si-RNA mediated knockdown of Aurora kinase B [39].

\section{Correlation of HPV status and Aurora kinase A polymorphism with overall survival}

The incidence of HPV-induced HNSCC in the oropharynx has significantly increased in recent years, and especially among men, the incidence is raising drastically $[9,63,64]$. Overall, the prevalence of HPV infection in HNSCC varies from approximately $25-43 \%$, depending on the location and method used to determine HPV status [12, 11, 65-67]; in this study we identified 49.5\% HPV samples.

It has been frequently reported that HPV infection not only contributes to the development of tumors, but also represents a favorable prognostic marker for the survival of patients with HNSCC. A positive HPV status correlates with a prolonged overall survival [41,68-72], which we have confirmed in the present study. In contrast to the impact of HPV infection, high expression of tumor associated Aurora kinase A correlates with a pronounced increase in tumor progression, and consequently a shortened overall survival of the patients [37, 51, 73, 74]. This is in agreement with the findings reported by Reiter et al. [37]. In addition, clinically relevant associations between the polymorphism of Aurora kinase A and the outcome of disease have been identified [31]. For example, Aurora kinase A is suspected to initiate cell migration and invasion and thus increase the metastatic potential of HNSCC [75]. However, the predictive power of the AurkA polymorphism on overall survival remains controversial. Although Royce et al. detected Aurora kinase A overexpression in the tumor tissue, this did not correlate with the prognosis of the patients [76]. Results from our research group confirm this, as there was no detectable association between the Aurora kinase A polymorphism and overall patient survival [62,39]. However, the literature clearly raises suspicion that the Aurora kinase A polymorphism significantly increases the risk of developing malignancy [77], and also plays a crucial role in the response to treatment. We previously demonstrated that the Aurora kinase A polymorphism significantly correlated with the response to treatment with the EGF receptor antibody cetuximab in vitro. We showed that homozygous HNSCC cells harboring the AurkA Phe/Phe genotype were sensitive to cetuximab treatment; by contrast, clonogenic survival of cells with a heterozygous genotype (Phe/lle Aurora kinase A) could not be impaired by cetuximab. The inhibition of Aurora kinase A with specific si-RNA in combination with cetuximab also led to a statistically significant reduction of colony formation only in the heterozygous Phe/lle cell line [39].

In the subsequent work of 2018, the relevance of the Aurora kinase A polymorphism in terms of therapeutic response was confirmed in vitro. Correlation analyzes revealed a significantly better response to specific inhibition therapy in the AurkA heterozygous Phe/lle cell line [62].

These varying results can be explained by several aspects. In the previous study, the treatment with the monoclonal antibody cetuximab was specifically investigated, whereas in the later work docetaxel with specific Aurora kinase inhibitors was used. On the other hand, in 2014 the survival data was derived from a colony formation assay, while in 2018 cell viability was assessed. 


\section{Conclusions}

In order to estimate the impact of the Aurora kinase A Phe31lle polymorphism on the outcome of HNSCC disease in greater detail, a prospective study in the palliative setting is needed. Prospectively, the AurkA polymorphism, together with the HPV status, could contribute to an enhanced patient stratification that might be relevant for therapeutic decision-making. A prerequisite for improved treatment efficacy is an accurate and precise diagnostic determination of the presence of HPV infection and Aurora kinase A Phe31lle polymorphism.

\section{Declarations}

\section{Ethics approval and consent to participate}

The study with all experimental protocols were approved by the Ethics Committee of the Klinikum rechts der Isar, Technical University Munich (project number 1420/05). All methods were carried out in accordance with relevant guidelines and regulations. Informed consent was obtained from all subjects.

\section{Consent for publication}

Not applicable.

\section{Availability of data and materials}

The datasets used and/or analysed during the current study are available from the corresponding author on reasonable request.

\section{Competing interests}

The authors declare that they have no competing interests.

\section{Funding}

No funding obtained.

\section{Authors' contributions}

JM analyzed and interpreted the data and wrote the manuscript.

AR was a major contributor in writing the manuscript.

MS was involved in conceptualization and methodology.

GP was a major contributor in analyzing and interpreting the in vitro experiments.

RR was involved in formal analysis. 
MW was a major contributor in study design and helped with data curation.

GB was involved in methodology and in vitro experiments.

WW helped with data curation and provided patient data.

AP was head of project administration and a major contributor in writing the manuscript.

All authors read and approved the final manuscript.

\section{Acknowledgements}

Not applicable.

\section{References}

1. Hunt JL, Barnes L, Lewis JS, Jr., Mahfouz ME, Slootweg PJ, Thompson LD et al. Molecular diagnostic alterations in squamous cell carcinoma of the head and neck and potential diagnostic applications. Eur Arch Otorhinolaryngol. 2014;271(2):211-23. doi:10.1007/s00405-013-2400-9.

2. Hunter KD, Parkinson EK, Harrison PR. Profiling early head and neck cancer. Nat Rev Cancer. 2005;5(2):127-35. doi:10.1038/nrc1549.

3. Patel V, Leethanakul C, Gutkind JS. New approaches to the understanding of the molecular basis of oral cancer. Crit Rev Oral Biol Med. 2001;12(1):55-63.

4. Ferlay J, Shin HR, Bray F, Forman D, Mathers C, Parkin DM. Estimates of worldwide burden of cancer in 2008: GLOBOCAN 2008. Int J Cancer. 2010;127(12):2893-917. doi:10.1002/ijc.25516.

5. Barnes L, International Agency for Research on C, World Health O, International Academy of $P$, Universitäts-Spital Z. Pathology and genetics of head and neck tumours. WHO classification of head and neck tumors, vol 430 p. Lyon: IARC Press; 2007.

6. Chung $\mathrm{CH}$, Gillison ML. Human papillomavirus in head and neck cancer: its role in pathogenesis and clinical implications. Clin Cancer Res. 2009;15(22):6758-62. doi:10.1158/1078-0432.CCR-09-0784.

7. Michl P, Pazdera J, Prochazka M, Pink R, Stosova T. Human papillomavirus in the etiology of head and neck carcinomas. Biomed Pap Med Fac Univ Palacky Olomouc Czech Repub. 2010;154(1):9-12.

8. Windon MJ, D'Souza G, Rettig EM, Westra WH, van Zante A, Wang SJ et al. Increasing prevalence of human papillomavirus-positive oropharyngeal cancers among older adults. Cancer. 2018;124(14):2993-9. doi:10.1002/cncr.31385.

9. Chaturvedi AK, Engels EA, Pfeiffer RM, Hernandez BY, Xiao W, Kim E et al. Human papillomavirus and rising oropharyngeal cancer incidence in the United States. J Clin Oncol. 2011;29(32):4294-301. doi:10.1200/JC0.2011.36.4596.

10. Mehanna H, Beech T, Nicholson T, El-Hariry I, McConkey C, Paleri V et al. Prevalence of human papillomavirus in oropharyngeal and nonoropharyngeal head and neck cancer-systematic review 
and meta-analysis of trends by time and region. Head Neck. 2013;35(5):747-55. doi:10.1002/hed.22015.

11. Kreimer AR, Clifford GM, Boyle P, Franceschi S. Human papillomavirus types in head and neck squamous cell carcinomas worldwide: a systematic review. Cancer Epidemiol Biomarkers Prev. 2005;14(2):467-75. doi:10.1158/1055-9965.EPI-04-0551.

12. Gillison ML, Koch WM, Capone RB, Spafford M, Westra WH, Wu L et al. Evidence for a causal association between human papillomavirus and a subset of head and neck cancers. J Natl Cancer Inst. 2000;92(9):709-20.

13. Leemans CR, Braakhuis BJ, Brakenhoff RH. The molecular biology of head and neck cancer. Nat Rev Cancer. 2011;11(1):9-22. doi:10.1038/nrc2982.

14. Stadler ME, Patel MR, Couch ME, Hayes DN. Molecular biology of head and neck cancer: risks and pathways. Hematol Oncol Clin North Am. 2008;22(6):1099-124, vii. doi:10.1016/j.hoc.2008.08.007.

15. Grandis JR, Tweardy DJ. Elevated levels of transforming growth factor alpha and epidermal growth factor receptor messenger RNA are early markers of carcinogenesis in head and neck cancer. Cancer Res. 1993;53(15):3579-84.

16. Ke LD, Adler-Storthz K, Clayman GL, Yung AW, Chen Z. Differential expression of epidermal growth factor receptor in human head and neck cancers. Head Neck. 1998;20(4):320-7.

17. Freier K, Joos S, Flechtenmacher C, Devens F, Benner A, Bosch FX et al. Tissue microarray analysis reveals site-specific prevalence of oncogene amplifications in head and neck squamous cell carcinoma. Cancer Res. 2003;63(6):1179-82.

18. Koynova DK, Tsenova VS, Jankova RS, Gurov PB, Toncheva DI. Tissue microarray analysis of EGFR and HER2 oncogene copy number alterations in squamous cell carcinoma of the larynx. J Cancer Res Clin Oncol. 2005;131(3):199-203. doi:10.1007/s00432-004-0627-y.

19. Sharafinski ME, Ferris RL, Ferrone S, Grandis JR. Epidermal growth factor receptor targeted therapy of squamous cell carcinoma of the head and neck. Head Neck. 2010;32(10):1412-21. doi:10.1002/hed.21365.

20. Temam S, Kawaguchi H, El-Naggar AK, Jelinek J, Tang H, Liu DD et al. Epidermal growth factor receptor copy number alterations correlate with poor clinical outcome in patients with head and neck squamous cancer. J Clin Oncol. 2007;25(16):2164-70. doi:10.1200/JC0.2006.06.6605.

21. Diasio RB, Fourie J. Targeting the epidermal growth factor receptor in the treatment of colorectal cancer: state of the art. Drugs. 2006;66(11):1441-63.

22. Ciardiello F, Tortora G. A novel approach in the treatment of cancer: targeting the epidermal growth factor receptor. Clin Cancer Res. 2001;7(10):2958-70.

23. Zhang N, Erjala K, Kulmala J, Qiu X, Sundvall M, Elenius K et al. Concurrent cetuximab, cisplatin, and radiation for squamous cell carcinoma of the head and neck in vitro. Radiother Oncol. 2009;92(3):388-92. doi:10.1016/j.radonc.2009.04.019.

24. Glover DM, Leibowitz MH, McLean DA, Parry H. Mutations in aurora prevent centrosome separation leading to the formation of monopolar spindles. Cell. 1995;81(1):95-105. 
25. Kollareddy M, Zheleva D, Dzubak P, Brahmkshatriya PS, Lepsik M, Hajduch M. Aurora kinase inhibitors: progress towards the clinic. Invest New Drugs. 2012;30(6):2411-32. doi:10.1007/s10637012-9798-6.

26. Marumoto T, Zhang D, Saya H. Aurora-A - a guardian of poles. Nat Rev Cancer. 2005;5(1):42-50. doi:10.1038/nrc1526.

27. Mehra R, Serebriiskii IG, Burtness B, Astsaturov I, Golemis EA. Aurora kinases in head and neck cancer. Lancet Oncol. 2013;14(10):e425-35. doi:10.1016/S1470-2045(13)70128-1.

28. Andrews PD, Knatko E, Moore WJ, Swedlow JR. Mitotic mechanics: the auroras come into view. Curr Opin Cell Biol. 2003;15(6):672-83.

29. Bischoff JR, Anderson L, Zhu Y, Mossie K, Ng L, Souza B et al. A homologue of Drosophila aurora kinase is oncogenic and amplified in human colorectal cancers. EMBO J. 1998;17(11):3052-65. doi:10.1093/emboj/17.11.3052.

30. Landen CN, Jr., Lin YG, Immaneni A, Deavers MT, Merritt WM, Spannuth WA et al. Overexpression of the centrosomal protein Aurora-A kinase is associated with poor prognosis in epithelial ovarian cancer patients. Clin Cancer Res. 2007;13(14):4098-104. doi:10.1158/1078-0432.CCR-07-0431.

31. Miao X, Sun T, Wang Y, Zhang X, Tan W, Lin D. Functional STK15 Phe31lle polymorphism is associated with the occurrence and advanced disease status of esophageal squamous cell carcinoma. Cancer Res. 2004;64(8):2680-3.

32. Ogawa E, Takenaka K, Katakura H, Adachi M, Otake Y, Toda Y et al. Perimembrane Aurora-A expression is a significant prognostic factor in correlation with proliferative activity in non-small-cell lung cancer (NSCLC). Ann Surg Oncol. 2008;15(2):547-54. doi:10.1245/s10434-007-9653-8.

33. Tanaka E, Hashimoto Y, Ito T, Okumura T, Kan T, Watanabe G et al. The clinical significance of Aurora-A/STK15/BTAK expression in human esophageal squamous cell carcinoma. Clin Cancer Res. 2005;11(5):1827-34. doi:10.1158/1078-0432.CCR-04-1627.

34. Meraldi P, Honda R, Nigg EA. Aurora-A overexpression reveals tetraploidization as a major route to centrosome amplification in p53-/- cells. EMBO J. 2002;21(4):483-92.

35. Gu J, Gong Y, Huang M, Lu C, Spitz MR, Wu X. Polymorphisms of STK15 (Aurora-A) gene and lung cancer risk in Caucasians. Carcinogenesis. 2007;28(2):350-5. doi:10.1093/carcin/bgl149.

36. Mazumdar A, Henderson YC, El-Naggar AK, Sen S, Clayman GL. Aurora kinase A inhibition and paclitaxel as targeted combination therapy for head and neck squamous cell carcinoma. Head Neck. 2009;31(5):625-34. doi:10.1002/hed.21007.

37. Reiter R, Gais P, Jutting U, Steuer-Vogt MK, Pickhard A, Bink K et al. Aurora kinase A messenger RNA overexpression is correlated with tumor progression and shortened survival in head and neck squamous cell carcinoma. Clin Cancer Res. 2006;12(17):5136-41. doi:10.1158/1078-0432.CCR-051650.

38. Ewart-Toland A, Briassouli P, de Koning JP, Mao JH, Yuan J, Chan F et al. Identification of Stk6/STK15 as a candidate low-penetrance tumor-susceptibility gene in mouse and human. Nat Genet. 2003;34(4):403-12. doi:10.1038/ng1220. 
39. Pickhard A, Siegl M, Baumann A, Huhn M, Wirth M, Reiter R et al. The response of head and neck squamous cell carcinoma to cetuximab treatment depends on Aurora kinase A polymorphism. Oncotarget. 2014;5(14):5428-38. doi:10.18632/oncotarget.2117.

40. Schauer A, Rothe H, Balzer I, Fiebig I, Rauschecker H. [Immunohistochemical tumor diagnosis in breast cancer-use for assessing the stage and biology of so-called "small breast cancer"]. Rontgenblatter. 1988;41(8):340-4.

41. Ang KK, Harris J, Wheeler R, Weber R, Rosenthal DI, Nguyen-Tan PF et al. Human papillomavirus and survival of patients with oropharyngeal cancer. N Engl J Med. 2010;363(1):24-35. doi:10.1056/NEJMoa0912217.

42. Chau NG, Hammerman PS. Heads Up! Predictive Gene Signatures in Head and Neck Cancer May Be Coming Soon. Clin Cancer Res. 2016;22(15):3710-2. doi:10.1158/1078-0432.CCR-16-0582.

43. Weidhaas JB, Harris J, Schaue D, Chen AM, Chin R, Axelrod R et al. The KRAS-Variant and Cetuximab Response in Head and Neck Squamous Cell Cancer: A Secondary Analysis of a Randomized Clinical Trial. JAMA Oncol. 2017;3(4):483-91. doi:10.1001/jamaoncol.2016.5478.

44. Johnson N. Tobacco use and oral cancer: a global perspective. J Dent Educ. 2001;65(4):328-39.

45. Wynder EL, Stellman SD. Comparative epidemiology of tobacco-related cancers. Cancer Res. 1977;37(12):4608-22.

46. Zhou H, Kuang J, Zhong L, Kuo WL, Gray JW, Sahin A et al. Tumour amplified kinase STK15/BTAK induces centrosome amplification, aneuploidy and transformation. Nat Genet. 1998;20(2):189-93. doi:10.1038/2496.

47. Erpolat OP, Gocun PU, Akmansu M, Karakus E, Akyol G. High expression of nuclear survivin and Aurora B predicts poor overall survival in patients with head and neck squamous cell cancer. Strahlenther Onkol. 2012;188(3):248-54. doi:10.1007/s00066-011-0042-7.

48. Jaiswal PK, Goel A, Mittal RD. Survivin: A molecular biomarker in cancer. Indian J Med Res. 2015;141(4):389-97. doi:10.4103/0971-5916.159250.

49. Pedrero JM, Carracedo DG, Pinto CM, Zapatero AH, Rodrigo JP, Nieto CS et al. Frequent genetic and biochemical alterations of the PI 3-K/AKT/PTEN pathway in head and neck squamous cell carcinoma. Int J Cancer. 2005;114(2):242-8. doi:10.1002/ijc.20711.

50. Qi G, Kudo Y, Ando T, Tsunematsu T, Shimizu N, Siriwardena SB et al. Nuclear Survivin expression is correlated with malignant behaviors of head and neck cancer together with Aurora-B. Oral Oncol. 2010;46(4):263-70. doi:10.1016/j.oraloncology.2010.01.004.

51. Zhang PL, Pellitteri PK, Law A, Gilroy PA, Wood GC, Kennedy TL et al. Overexpression of phosphorylated nuclear factor-kappa B in tonsillar squamous cell carcinoma and high-grade dysplasia is associated with poor prognosis. Mod Pathol. 2005;18(7):924-32. doi:10.1038/modpathol.3800372.

52. Testa JR, Bellacosa A. AKT plays a central role in tumorigenesis. Proc Natl Acad Sci U S A. 2001;98(20):10983-5. doi:10.1073/pnas.211430998. 
53. Bannister AJ, Kouzarides T. Regulation of chromatin by histone modifications. Cell Res. 2011;21(3):381-95. doi:10.1038/cr.2011.22.

54. Dohi T, Okada K, Xia F, Wilford CE, Samuel T, Welsh K et al. An IAP-IAP complex inhibits apoptosis. J Biol Chem. 2004;279(33):34087-90. doi:10.1074/jbc.C400236200.

55. Hochegger $\mathrm{H}$, Hegarat N, Pereira-Leal JB. Aurora at the pole and equator: overlapping functions of Aurora kinases in the mitotic spindle. Open Biol. 2013;3(3):120185. doi:10.1098/rsob.120185.

56. Knauer SK, Mann W, Stauber RH. Survivin's dual role: an export's view. Cell Cycle. 2007;6(5):518-21. doi:10.4161/cc.6.5.3902.

57. Lens SM, Medema RH. The survivin/Aurora B complex: its role in coordinating tension and attachment. Cell Cycle. 2003;2(6):507-10. doi:10.4161/cc.2.6.559.

58. Kitagawa M, Lee SH. The chromosomal passenger complex (CPC) as a key orchestrator of orderly mitotic exit and cytokinesis. Front Cell Dev Biol. 2015;3:14. doi:10.3389/fcell.2015.00014.

59. Giet R, Petretti C, Prigent C. Aurora kinases, aneuploidy and cancer, a coincidence or a real link? Trends Cell Biol. 2005;15(5):241-50. doi:10.1016/j.tcb.2005.03.004.

60. Boeckx C, Op de Beeck K, Wouters A, Deschoolmeester V, Limame R, Zwaenepoel K et al. Overcoming cetuximab resistance in HNSCC: the role of AURKB and DUSP proteins. Cancer Lett. 2014;354(2):36577. doi:10.1016/j.canlet.2014.08.039.

61. Gonzalez-Loyola A, Fernandez-Miranda G, Trakala M, Partida D, Samejima K, Ogawa H et al. Aurora B Overexpression Causes Aneuploidy and p21Cip1 Repression during Tumor Development. Mol Cell Biol. 2015;35(20):3566-78. doi:10.1128/MCB.01286-14.

62. Baumann A, Buchberger AMS, Piontek G, Schuttler D, Rudelius M, Reiter R et al. The Aurora-Kinase A Phe31-lle polymorphism as possible predictor of response to treatment in head and neck squamous cell carcinoma. Oncotarget. 2018;9(16):12769-80. doi:10.18632/oncotarget.24355.

63. Gillison ML, Chaturvedi AK, Anderson WF, Fakhry C. Epidemiology of Human Papillomavirus-Positive Head and Neck Squamous Cell Carcinoma. J Clin Oncol. 2015;33(29):3235-42. doi:10.1200/JC0.2015.61.6995.

64. Hong AM, Grulich AE, Jones D, Lee CS, Garland SM, Dobbins TA et al. Squamous cell carcinoma of the oropharynx in Australian males induced by human papillomavirus vaccine targets. Vaccine. 2010;28(19):3269-72. doi:10.1016/j.vaccine.2010.02.098.

65. McKaig RG, Baric RS, Olshan AF. Human papillomavirus and head and neck cancer: epidemiology and molecular biology. Head Neck. 1998;20(3):250-65.

66. Mellin H, Friesland S, Lewensohn R, Dalianis T, Munck-Wikland E. Human papillomavirus (HPV) DNA in tonsillar cancer: clinical correlates, risk of relapse, and survival. Int J Cancer. 2000;89(3):300-4.

67. Wilczynski SP, Lin BT, Xie Y, Paz IB. Detection of human papillomavirus DNA and oncoprotein overexpression are associated with distinct morphological patterns of tonsillar squamous cell carcinoma. Am J Pathol. 1998;152(1):145-56. 
68. Dok R, Nuyts S. HPV Positive Head and Neck Cancers: Molecular Pathogenesis and Evolving Treatment Strategies. Cancers (Basel). 2016;8(4). doi:10.3390/cancers8040041.

69. Fakhry C, Westra WH, Li S, Cmelak A, Ridge JA, Pinto H et al. Improved survival of patients with human papillomavirus-positive head and neck squamous cell carcinoma in a prospective clinical trial. J Natl Cancer Inst. 2008;100(4):261-9. doi:10.1093/jnci/djn011.

70. Kimple RJ, Harari PM. The prognostic value of HPV in head and neck cancer patients undergoing postoperative chemoradiotherapy. Ann Transl Med. 2015;3(Suppl 1):S14. doi:10.3978/j.issn.23055839.2015.01.37.

71. Lassen P, Eriksen JG, Hamilton-Dutoit S, Tramm T, Alsner J, Overgaard J. Effect of HPV-associated p16INK4A expression on response to radiotherapy and survival in squamous cell carcinoma of the head and neck. J Clin Oncol. 2009;27(12):1992-8. doi:10.1200/JC0.2008.20.2853.

72. Lohaus F, Linge A, Tinhofer I, Budach V, Gkika E, Stuschke M et al. HPV16 DNA status is a strong prognosticator of loco-regional control after postoperative radiochemotherapy of locally advanced oropharyngeal carcinoma: results from a multicentre explorative study of the German Cancer Consortium Radiation Oncology Group (DKTK-ROG). Radiother Oncol. 2014;113(3):317-23. doi:10.1016/j.radonc.2014.11.011.

73. Neben K, Korshunov A, Benner A, Wrobel G, Hahn M, Kokocinski F et al. Microarray-based screening for molecular markers in medulloblastoma revealed STK15 as independent predictor for survival. Cancer Res. 2004;64(9):3103-11.

74. Tong T, Zhong Y, Kong J, Dong L, Song Y, Fu M et al. Overexpression of Aurora-A contributes to malignant development of human esophageal squamous cell carcinoma. Clin Cancer Res. 2004;10(21):7304-10. doi:10.1158/1078-0432.CCR-04-0806.

75. Wu J, Yang L, Shan Y, Cai C, Wang S, Zhang H. AURKA promotes cell migration and invasion of head and neck squamous cell carcinoma through regulation of the AURKA/Akt/FAK signaling pathway. Oncol Lett. 2016;11(3):1889-94. doi:10.3892/ol.2016.4110.

76. Royce ME, Xia W, Sahin AA, Katayama H, Johnston DA, Hortobagyi G et al. STK15/Aurora-A expression in primary breast tumors is correlated with nuclear grade but not with prognosis. Cancer. 2004;100(1):12-9. doi:10.1002/cncr.11879.

77. Tang W, Qiu H, Ding H, Sun B, Wang L, Yin J et al. Association between the STK15 F31I polymorphism and cancer susceptibility: a meta-analysis involving 43,626 subjects. PLoS One. 2013;8(12):e82790. doi:10.1371/journal.pone.0082790.

\section{Figures}



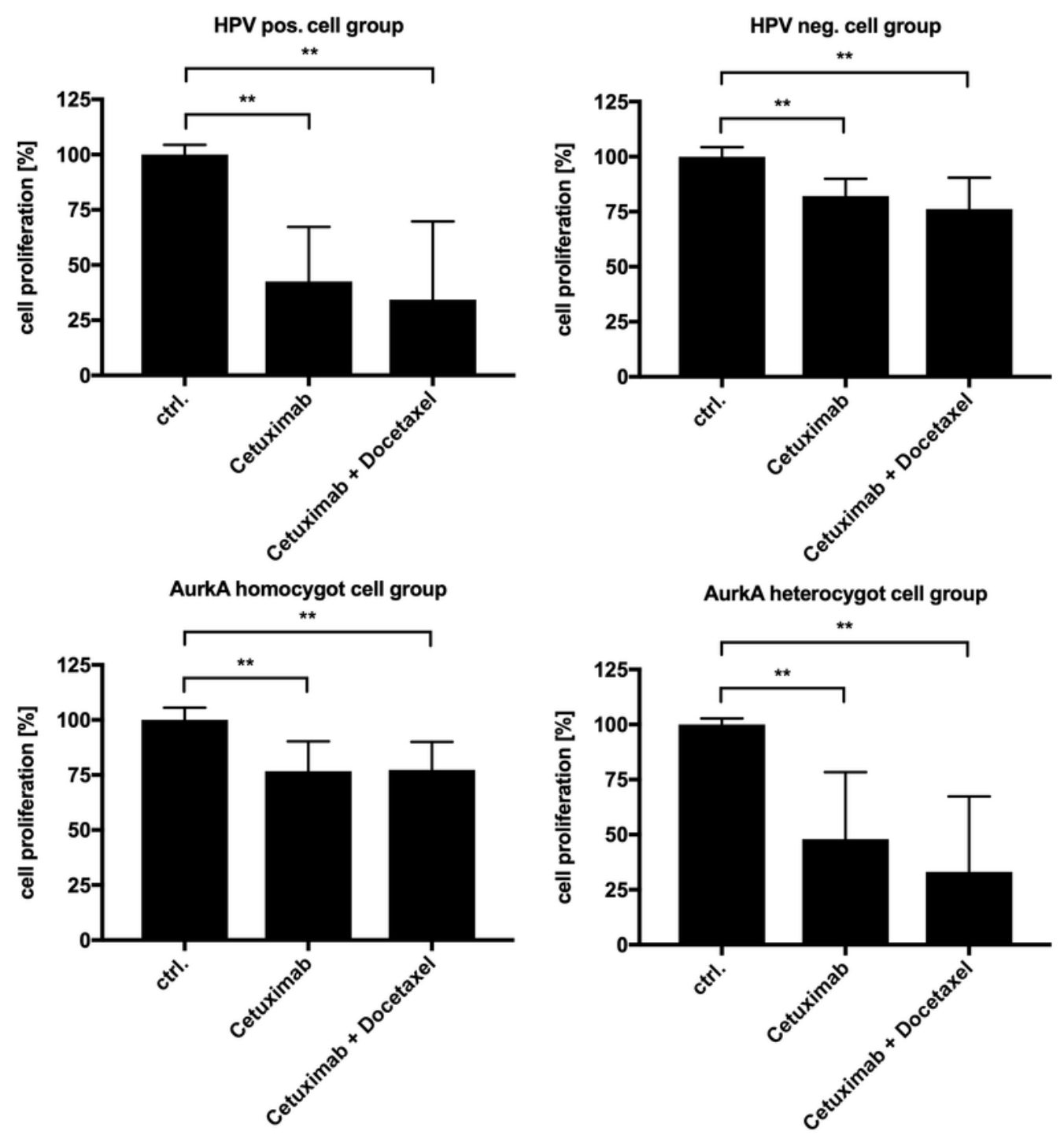

\begin{tabular}{|c|c|c|c|}
\hline cell group & treatment & p-value & significant \\
\hline \multirow{2}{*}{ HPV positive } & Cetuximab & 0.002 & yes $\left[{ }^{\star \star}\right]$ \\
\hline & Cetuximab + Docetaxel & 0.0054 & yes $\left[{ }^{* *}\right]$ \\
\hline \multirow{2}{*}{ HPV negative } & Cetuximab & 0.0013 & yes $\left[{ }^{\star \star}\right]$ \\
\hline & Cetuximab + Docetaxel & 0.0083 & yes $\left[{ }^{\star \star}\right]$ \\
\hline \multirow{2}{*}{ AurkA homocygot } & Cetuximab & 0.0067 & yes $\left[{ }^{\star *}\right]$ \\
\hline & Cetuximab + Docetaxel & 0.0054 & yes $\left[{ }^{\star *}\right]$ \\
\hline \multirow{2}{*}{ AurkA heterocygot } & Cetuximab & 0.0084 & yes $[* *]$ \\
\hline & Cetuximab + Docetaxel & 0.0044 & yes $\left[{ }^{* * *}\right]$ \\
\hline
\end{tabular}

\section{Figure 1}

Proliferation assay Treatment with cetuximab caused a significantly more efficient response in HPV positive (pos.) than in HPV negative (neg.) cells. The antiproliferative effect was even more pronounced in Aurora kinase A (AurkA) heterozygotes compared to AurkA homozygous cell lines ctrl. = control * $p<$ $0,05 * \star p<0,01 * \star \star p<0,001 * \star \star \star p<0,0001$ 

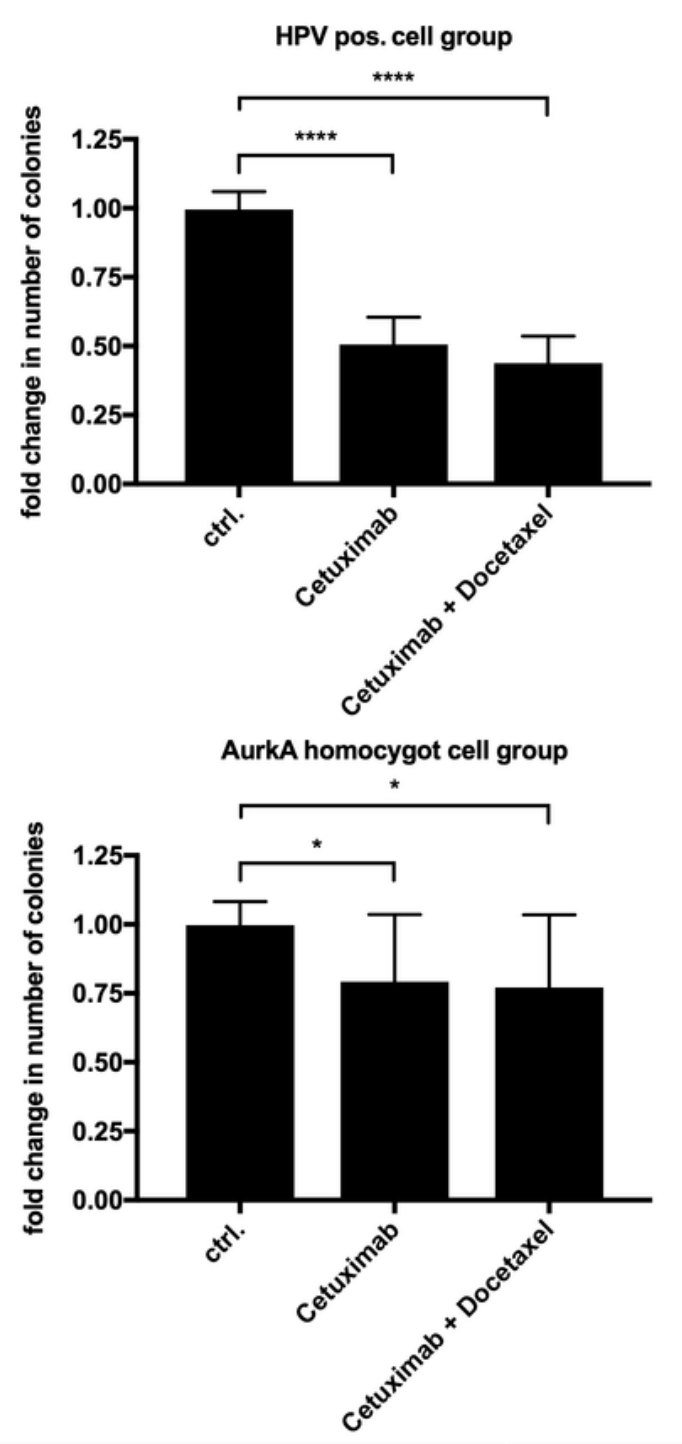

\begin{tabular}{|c|c|c|c|}
\hline cell group & treatment & p-value & significant \\
\hline HPV positive & Cetuximab & $<0.0001$ & yes $\left[{ }^{\star \star \star}\right]$ \\
\hline HPV negative & Cetuximab + Docetaxel & $<0.0001$ & yes $\left[{ }^{\star \star \star}\right]$ \\
\hline \multirow{2}{*}{ AurkA homocygot } & Cetuximab & 0.3559 & no \\
\hline & Cetuximab + Docetaxel & 0.0874 & no \\
\hline & Cetuximab & 0.016 & yes $\left[{ }^{\star}\right]$ \\
\hline AurkA heterocygot & Cetuximab + Docetaxel & 0.0142 & yes $\left[{ }^{\star}\right]$ \\
\hline & Cetuximab & 0.0012 & yes $\left.{ }^{\star \star}\right]$ \\
\hline
\end{tabular}

\section{Figure 2}

Colony formation assay HPV positive cells were significantly sensitive to the treatments. In contrast, the application of cetuximab alone or in combination with docetaxel did not elicit any effect on the clonogenic survival of HPV negative cells. Both cetuximab monotreatment and the combination treatment significantly reduced clonogenic formation of the Aurora kinase A (AurkA) homozygous and 
AurkA heterozygous cell lines ctrl. $=$ control * $p$-value $<0.05 * \star p$-value $<0.01 * \star \star p$-value $<0.001 * \star \star \star p-$ value $<0.0001$

HPV negative

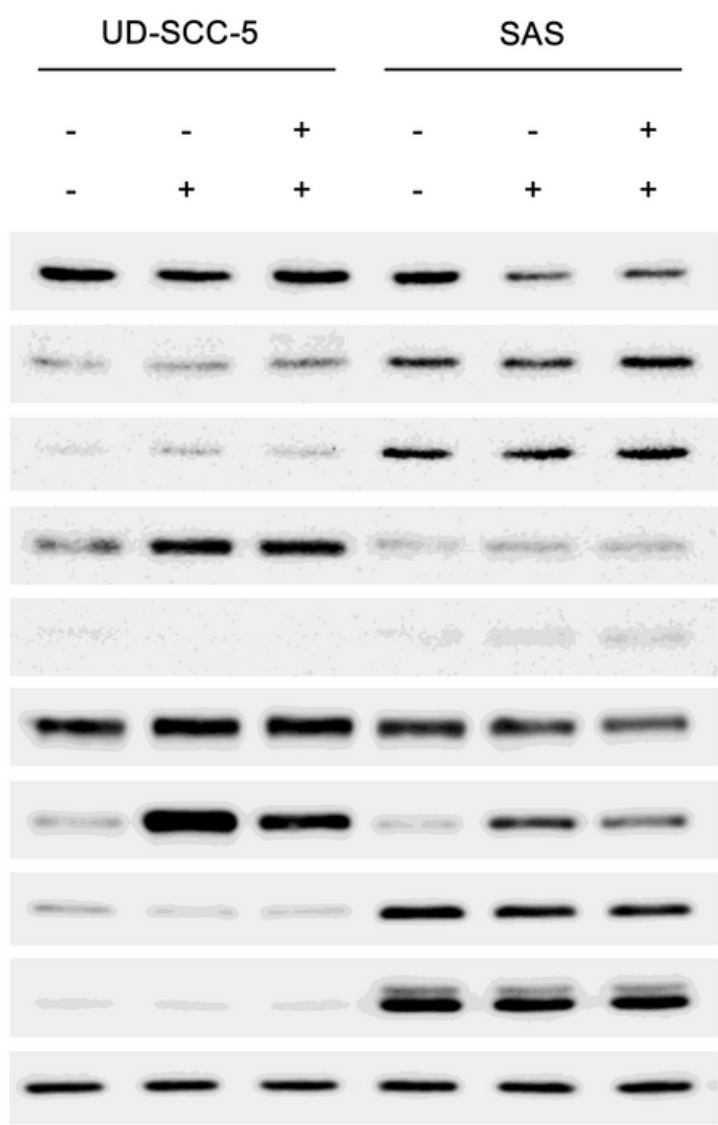

HPV positive

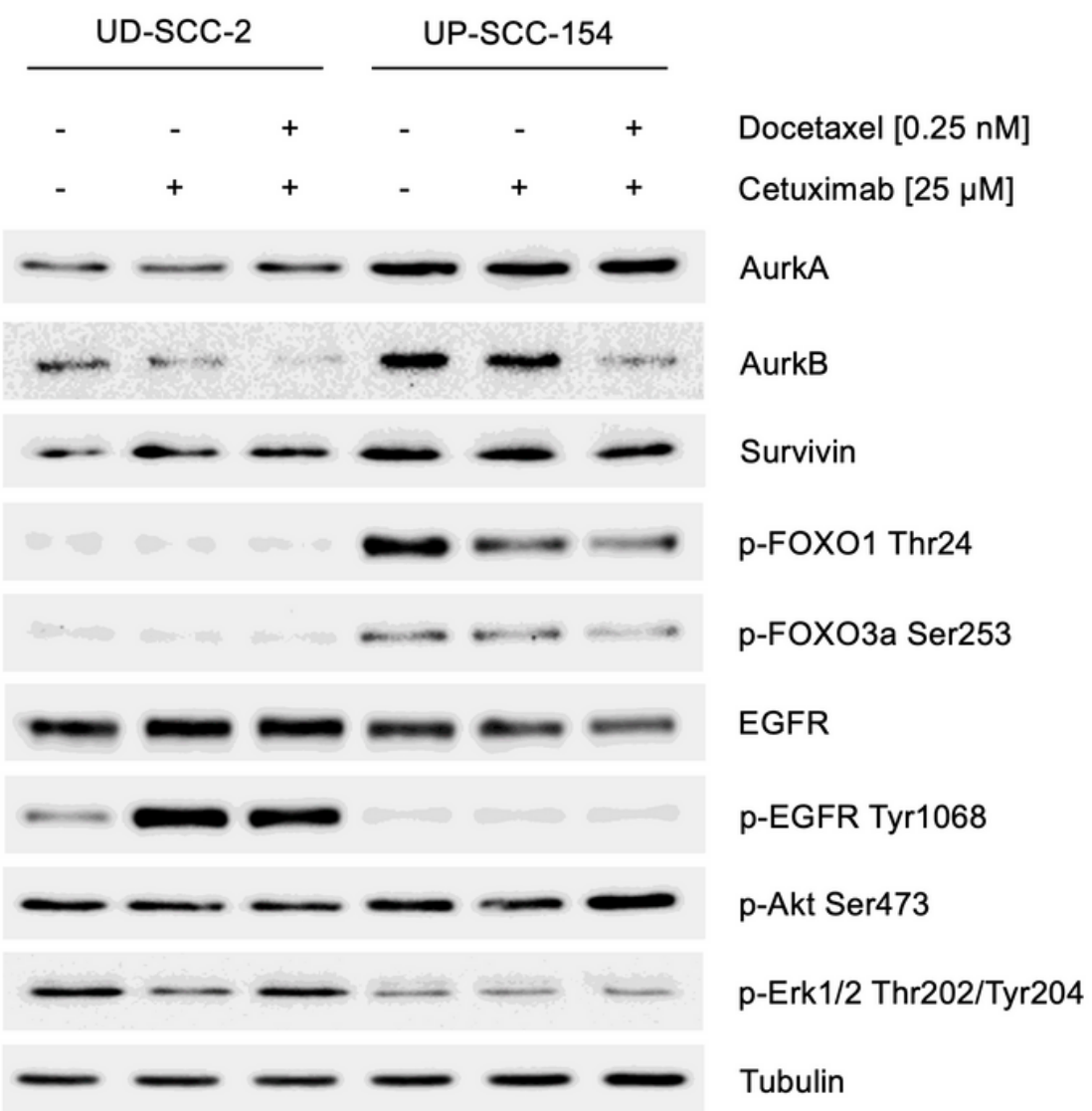

Figure 3

Western blot analysis Western blot analysis revealed higher protein levels of Survivin, p-Akt Ser473, and Aurora kinase B (AurkB) in the heterozygous cell lines (UP-SCC-154, SAS) compared to the homozygous cell lines (UD-SCC-5, UD-SCC-2). Treatment of the cells, in particular with the combination of cetuximab and docetaxel, led to a reduction of AurkA protein expression in the HPV negative cell lines. The strongest effect was observed in the homozygous UD-SCC-5 cell line 

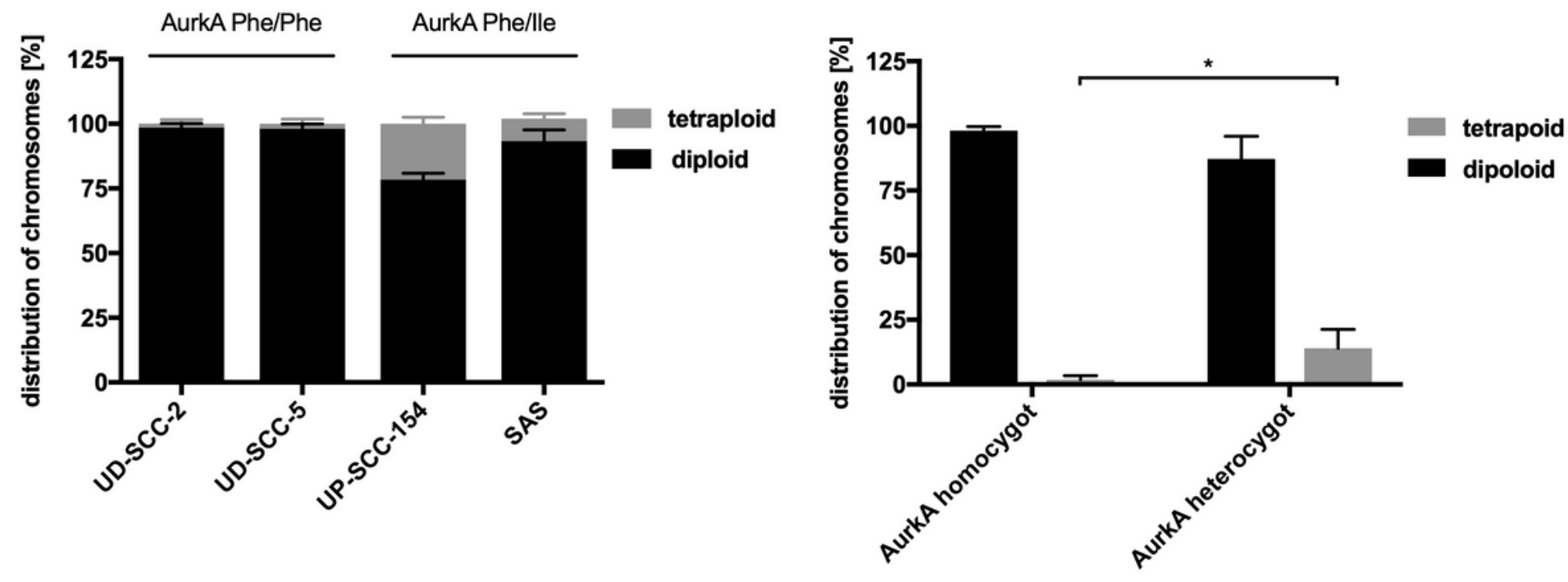

Figure 4

Ploidy analysis The two homozygous cell lines UD-SCC-2 and UD-SCC-5 were mostly diploid; tetraploid cells could be found in the heterozygous cell lines UP-SCC-154 and SAS. The difference in the number of tetraploid cells between cell lines with different Aurora kinase A (AurkA) polymorphisms was significant * p-value $=0.019$

A

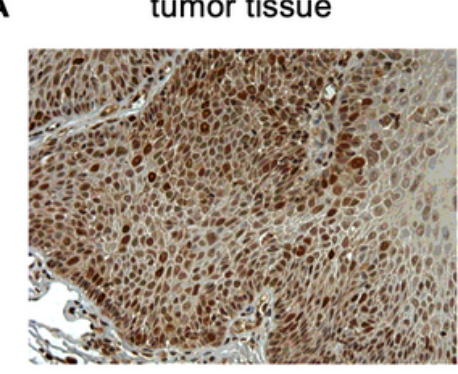

\section{AurkA}

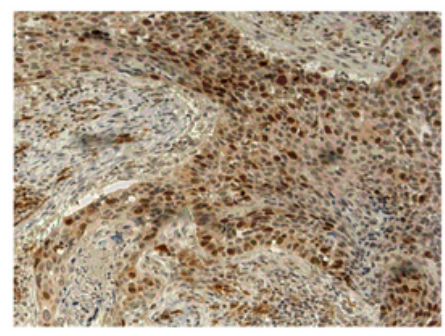

AurkB

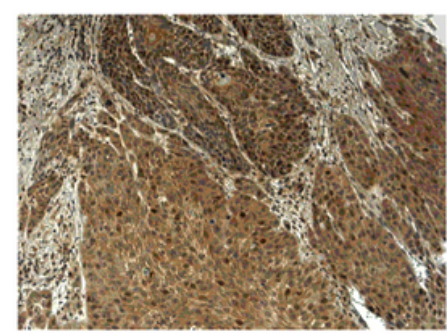

Survivin normal tissue
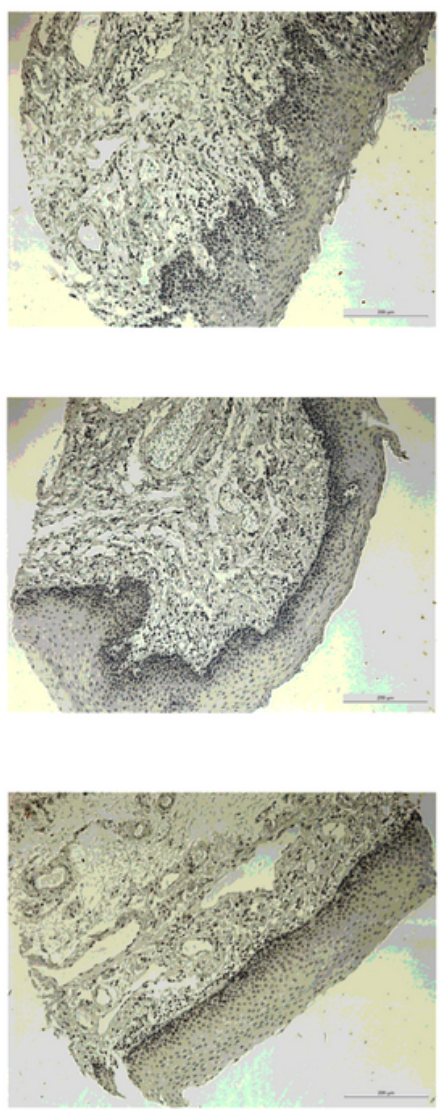

B tumor tissue, positive

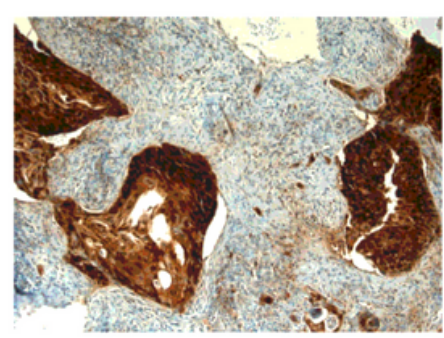

p16 INK4 tumor tissue, negative

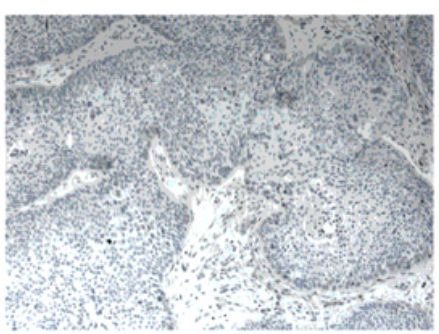


Exemplary presentation of immunohistochemistry results. A: Exemplary positive immunohistochemistry results of Aurora kinase A (AurkA), Aurora kinase B (AurkB) and Survivin in tumor tissue vs. normal tissue. $B$ : Exemplary positive and negative immunohistochemistry result of p16INK4 in tumor tissue

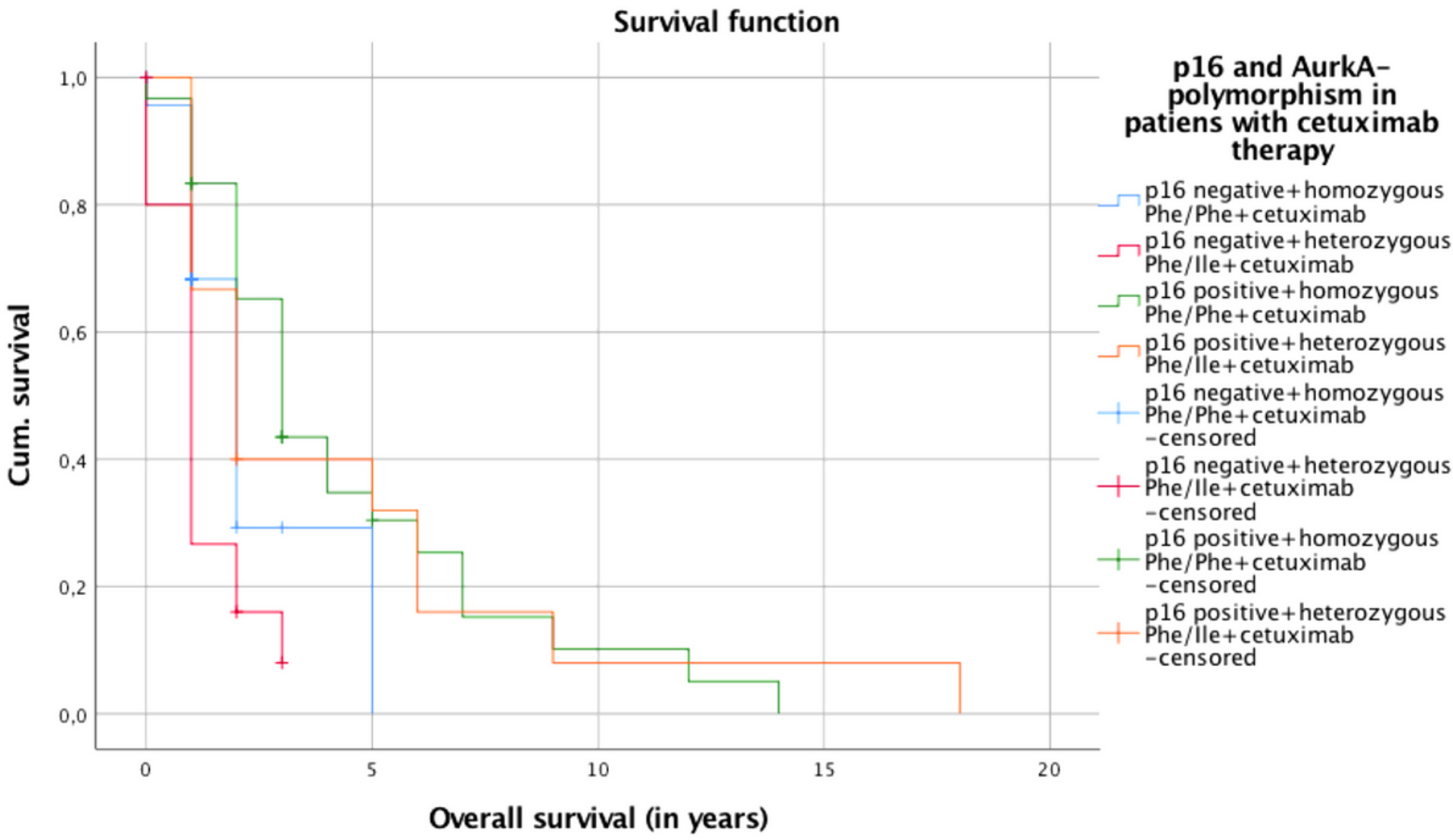

\section{Figure 6}

Kaplan-Maier analyses Kaplan-Meier curves for overall survival in patients with cetuximab therapy and homozygous Phe/Phe or heterozygous Phe/lle Aurora kinase A and p16 positive or p16 negative. p16 positive was found to be statistically significantly better for the prognosis in patients with cetuximab therapy $(p$-value $=0.001)$ 